九州大学学術情報リポジトリ

Kyushu University Institutional Repository

\title{
A New Schizophoriid Genus from the Akiyoshi Limestone : Carboniferous Brachiopods from Akiyoshi, Southwest Japan Part V
}

Yanagida, Juichi

Faculty of Science, Kyushu University

https://doi.org/10.5109/1546086

出版情報：九州大學理學部紀要：Series D, Geology. 25 (1)，pp.101-114，1983-11-15. Faculty of Science, Kyushu University バージョン：

権利関係 : 
Mem. Fac. Sci., Kyushu Univ., Ser. D, Geol., Vol. XXV, No. 1, pp. 101-114, text-figs. 1-8, tables 1-2, plates 14-15, November 15, 1983

\title{
A New Schizophoriid Genus from the Akiyoshi Limestone*
}

\author{
(Carboniferous Brachiopods from Akiyoshi, \\ Southwest Japan Part V)
}

Juichi YANAGIDA

\begin{abstract}
On the basis of more than one hundred specimens from the following fusulininan zones, the Millerella yowarensis zone, the Pseudostaffella antiqua zone, the Profusulinella beppensis zone, and the Fusulinella biconica zone, in the Carboniferous of the Akiyoshi limestone Group, a new schizophoriid genus, Neoschizophoria is proposed with Neoschizophoria otai gen. et sp. nov. as the type species. Brief remarks on the biostratigraphic significance and paleoecology of the species are also given.
\end{abstract}

\section{Introduction}

The Akiyoshi limestone Group, especially the Carboniferous part of it comprises many kinds of invertebrates in sufficient state of preservation. Many excellent contributions hitherto have been produced not only in the field of palaeontology and biostratigraphy but also in environmental analysis based on biofacies and lithofacies of the limestone. Brief outline of a large organic reef having been recognized in the uppermost Lower Carboniferous Millerella yowarensis zone and the successive Middle Carboniferous Pseudostaffella antiqua zone (OTA, M. 1968, Ota, N. et al., 1969, NAGAI, 1979). Fossiliferous limestones in the preceding fusuline zones mainly reflect the fore-reef facies and were characterized by abundant occurrence of branchiopods in association with bryozoans, molluses, corals and other reef builders such as stromatolites and chaetetids. A part of the brachiopod fauna was described by the author (1962, 1965) from the Uzura quarry of the Millerella yowarensis zone in northern part of the Nishinodai area.

Neoschizophoria otai, a new genus and new species occurs from five localities in the Nishinodai area, IW-1 (the Millerella yowarensis zone) at the Sumitomo quarry about $2 \mathrm{~km}$ SE of the Uzura quarry, ISA-41 and 42 (the Pseudostaffella antiqua zone) at the Maruyama quarry and ST-A** and $\mathrm{B}^{* *}$ (respectively the Profusulinella beppensis zone and the Fusulinella biconica zone) at Shoboji. Neoschizophoria otai occurs in association with a wide variety of brachiopods.

Thickness of limestone of each fossil zone in the Akiyoshi limestone Group

* Studies of Japanese Trilobites and Associated Fossils-XXVIII.

** ST-A and ST-B respectively corresponds to 74154 and 74136 of Hashimoto (1979). Manuscript received July 14, 1983. 


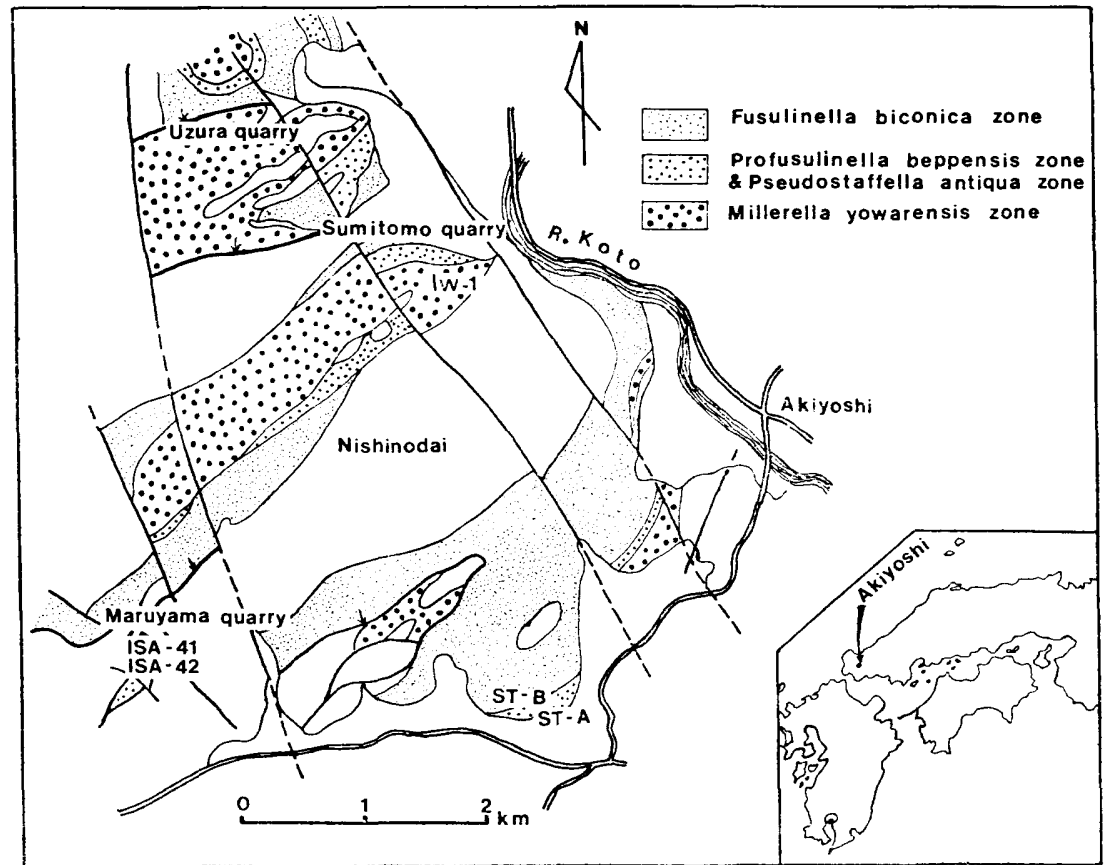

Fig. 1. Simplified geologic map of the Nishinodai area, showing localities of brachiopods and distribution of limestones of the Millerella yowarensis zone, Pseudostaffella antiqua zone, Profusulinella beppensis zone, and Fusulinella biconica zone.

was shown by OTA (1979). However, it is actually very difficult to make exact columnar sections of each fusuline zone as far as the Millerella yowarensis zone and the Pseudostaffella antiqua zone are concerned to mark the stratigraphic horizon of each brachiopod faunule on the columnar section. Because a large organic reef in the Akiyoshi limestone Group first appeared and rapidly developed in the Millerella yowarensis zone and expanded toward the Pseudostaffella antiqua zone. Therefore, unless the topographical outline of the organic reef in each fusuline zone is not confirmed, the exact thickness of limestones of the preceding two fusuline zones will not be correctly recognized.

Brachiopod faunules between the Uzura quarry and the IW-1 point are slightly different with each other in their age, though they belong to one and the same fusuline zone. The faunule of the Uzura quarry consists of 21 species among 17 genera and it is especially characterized by Cleiothyridina expansa (PhILliPs) and $\mathrm{Cl}$. royssii (L'EveILlÉ). These species together with bulk of specific elements of the faunule are well characterized by those of the Late Visean representatives in Western Europe. The faunule of IW-1 is undoubtedly younger than the other because of the complete absence of species of Cleiothyridina and Schizophoria aff. S. resupinata (MARTIN) and occurrence of Neoschizophoria otai and a very small number of Schizophoria connivens (PHILLIPS). Neoschizophoria otai at IW-1 is the first appearance in the Akiyoshi limestone and it ranges up to the Fusulinella biconica zone. Schizophoria connivens ranges 
in age from the Lowest Carboniferous up to the Middle Carboniferous Kinderscoutian $\left(\mathrm{R}_{1}\right)$ in Western Europe. Neoschizophoria otai also abundantly occurs in the Pseudostaffella antiqua zone at ISA-41 and 42 in association with other brachiopods of the Upper Carboniferous elements such as Choristites and Purdonella. These two localities, ISA-41 and 42, respectively correspond to IM-01 and 04 of NisHidA (1982) who described an ammonoid faunule, including 10 species among 10 genera from the same localities with brachiopods.

Summarizing the stratigraphic occurrence of the preceding brachiopod faunules, their biostratigraphic horizons and the relative abundance of Neoschizophoria otai in each of the faunules are shown as follows:

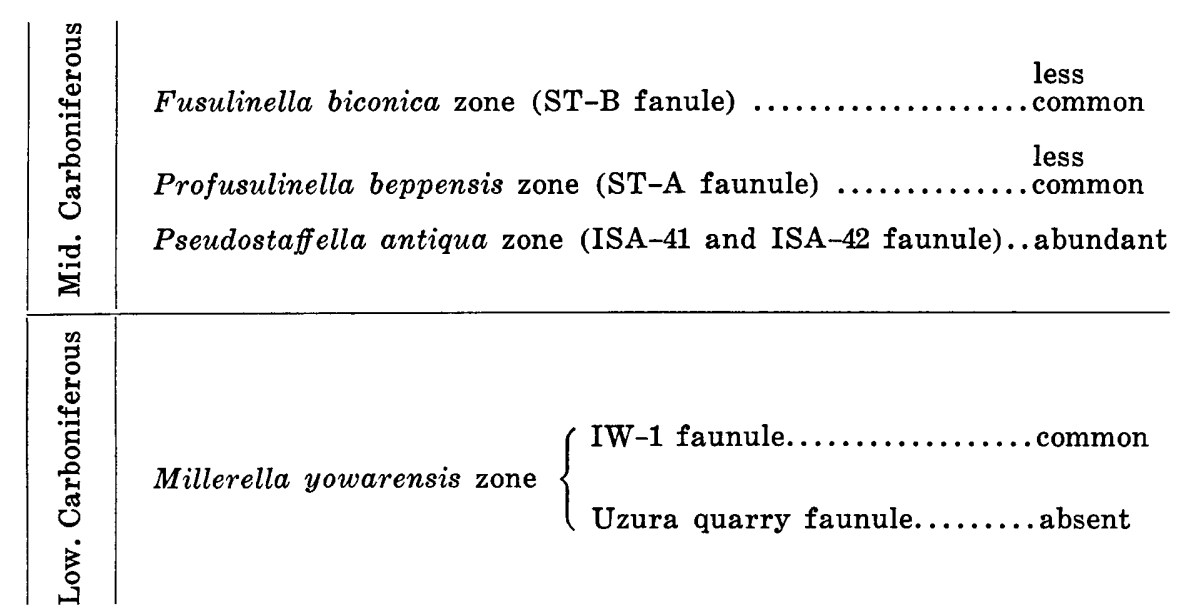

The author would express his sincere thanks to Drs. Masamichi OTA of the Kitakyushu City Museum of Natural History, Tamio NisHida of the Saga University, Messrs. Kyoichi Hashimoto of the Yamaguchi Prefectural Yamaguchi Museum, Akihiro Sugimura and Takehiko HaIkawa of the Akiyoshi-dai Museum of Natural History, and Koichi NAGAI of the Kyushu University for their continuous collaboration in collecting and providing fossils, and field survey. The author sincerely appreciates Dr. Teiichi Kobayashi, Professor Emeritus of the University of Tokyo for his continuous encouragements. The present study was financially supported by the Grants-in-Aid for Scientific Research for Japan Academy and Ministry of Education, Japan.

\section{Systematic Description}

Superfamily Enteletacea WAAGEN, 1884

Family Schizophoriidae Schuchert and LeVene, 1929

Genus Neoschizophoria nov.

Type-species.-Neoschizophoria otai YANAGIDA, gen. et sp. nov.

Diagnosis.-Medium to large and strongly dorsi-biconvex schizophoriidae externally with dorsal broad sulcus and internally with prominent cardinal 


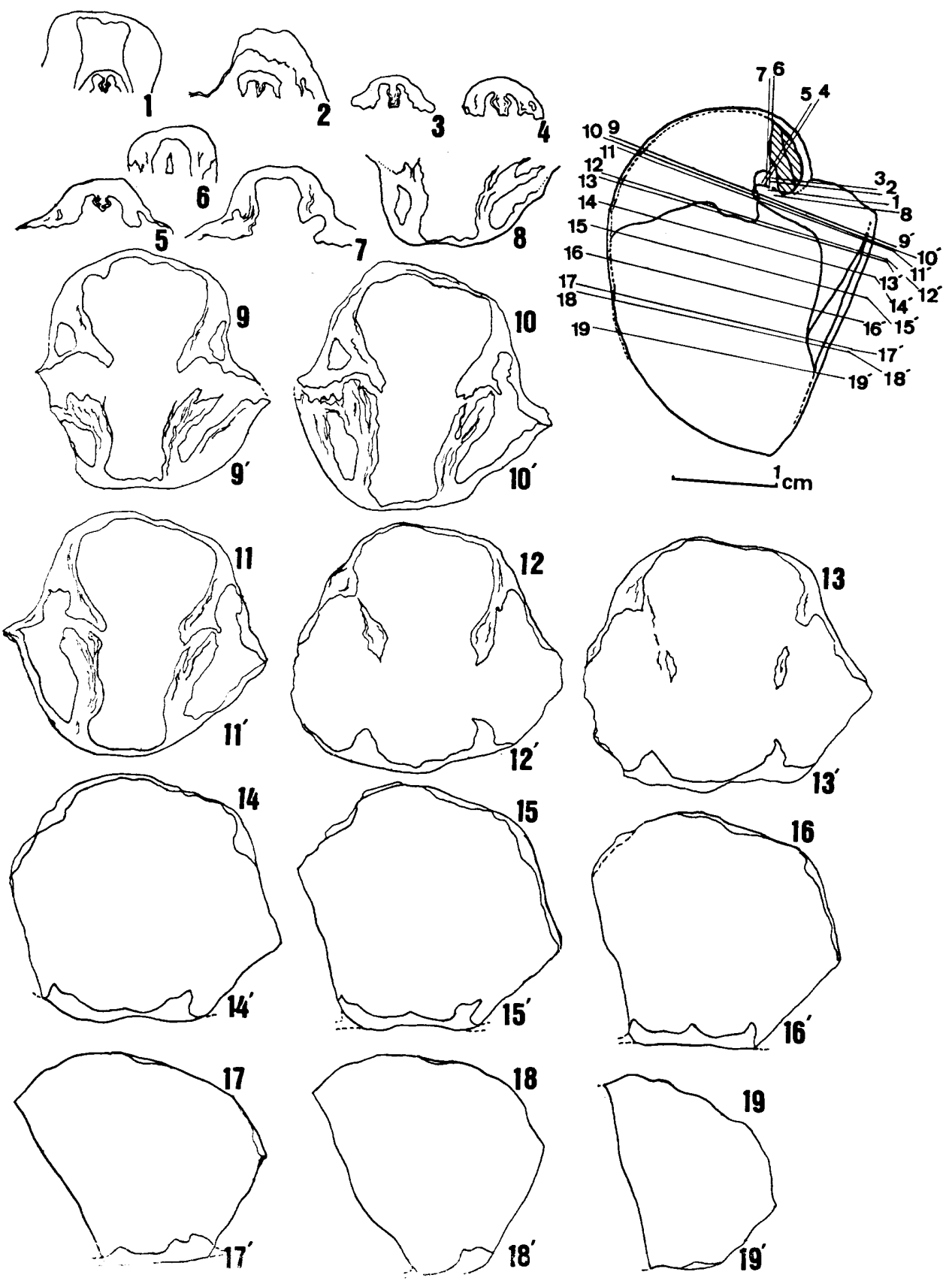

Fig. 2. Serial sections of a paratype specimen of Neoschizophoria otai gen. et sp. nov., GK-D 31717, from IW-1, the Millerella yowarensis zone, and a longitudinal profile of the same specimen, showing positions of each section and main internal structures. 
process with a median high lobe and a pair of low divergent accessory processes. Pedicle valve interarea flat and procline.

Description.-Shell medium to large, outline subrounded with very tumid dorsal umbo and very short hinge line, widest part at mid-length of shell; profile strongly dorsi-biconvex.

Brachial valve strongly convex longitudinally and transversely with moderately steep lateral slopes, broad and rather flattened median sector, and extremely incurved umbo; broad and shallow sulcus originates slightly anterior to umbonal region and increases width and depth anteriorly; pedicle valve with procline, high, narrow, and flat interarea, a pair of rounded and strong radial folds run antero-laterally from beak, distinguishing a flabellate and flat anteromedian area from a couple of narrow, elongated trigonal areas on valve surface. Both valves ornamented by fine rounded capillae; concentric growth liens densely arranged near margin. Anterior commissure very weakfily unisulcate.

Pedicle valve interior with stout teeth and thick, subparallel dental plates, anteriorly continuous to a pair of low stout ridges surrounding outer margin of muscle fields; anterior margin of muscle fields locates fairly anterior to midlength of valve. Brachial valve interior with deep notothyrial cavity, thick brachiophore supporting plates, strong brachiophores and broad sockets; anterior margin of muscle fields at about a half length of brachial valve; cardinal process stout and anteriorly trilobate with central, longitudinal high ridge and a pair of low accessory processes divergent from central one during growth.
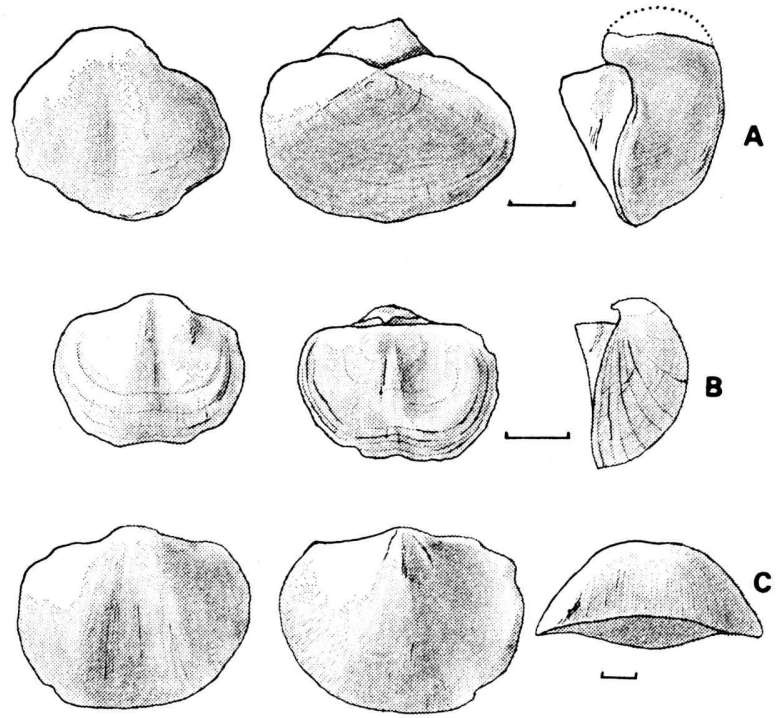

Fig. 3. Brief comparison of external forms of three related genera: A, Neoschizophoria otai gen. et sp. nov. (the holotype) ; B, Aulacophoria keyserlingiana (DE KONINCK) (after figures shown by WILliaMS and WRIGHT, 1965); C, Schizophoria resupinata (MARTIN) (after the neotype figures shown by BRUNTON, 1968). 
Discussion.-Dorsi-biconvex form, fine radial ornamentation and basic internal structures of both valves clearly reveal characters of schizophoriidae. Neoschizophoria is closely related to Schizophoria, however, from which the former is distinguished by the following characters: extraordinarily convex brachial valve with extremely incurved umbo and distinct broad sulcus; pedicle valve with procline, narrow interarea with very short hinge line, and the surface which is divided into three, nearly flat parts by a pair of antero-laterally radiated broad folds. Internally Neoschizophoria has a morphologically very characteristic cardinal process in the deep notothyrial cavity of branchial valve. The mode of shape and growth of the cardinal process are different from those of Schizophoria.

The morphology of the cardinal process of Schizophoria was shown by GEORGE and PONSFORD (1938) based on serial sections of several specimens of some British Lower Carboniferous species. BRUNTON (1968) discussed in detail on the cardinal process of Schizophoria based on abundant silicified specimens of Schizophoria resupinata dorsosinuata DEMANET from the Visean of Fermanagh, Ireland. Basically the form of the cardinal process of Neoschizophoria is similar to that of Schizophoria in having a median primary lobe and a pair of secondary accessory processes added during growth, consequently forming a trilobed structure. However, the accessory processes of Neoschizophoria are always originated from a laterally inflated, posterior basal part of the cardinal process where they branch off simultaneously and gradually increase in height and width during growth. The serial sections of a paratype specimen, GK-D 31718 (Fig. 4), well reveal the characteristic form of the cardinal process. The other sections of another paratype specimen, GK-D 31717 (Fig. 2), do not well show the detailed structure of the cardinal process. But the inflated basal part well shows a stage just before the appearance of accessory processes. Very stout, thick dental plates and brachiophore supporting plates together with very weak median ridges also help to recognize the Akiyoshi species as they belong to a distinct genus.

Among schizophoriid genera Aulacophoria from the Namurian of Western Europe is very close to Neoschizophoria in its strongly dorsi-biconvex form with strong development of a broad sulcus on brachial valve. Pedicle valve interarea of the former is high, flat and catacline. That of Neoschizophoria is also flat and high but constantly procline. The difference between Neoschizophoria and Aulacophoria is externally recognized on a narrow distinct fold on pedicle valve of the latter. Umbonal part of brachial valve of Aulacophoria is much less convex than Neoschizophoria. Moreover the dorsal sulcus of Aulacophoria originates from the umbonal part. That of Neoschizophoria, to the contrary, always appears slightly anterior to the umbonal portion as a very shallow broad depression.

LAZAREV (1976) treated Aulacophoria as a synonym of Schizophoria mainly because of the weakness of the narrow ventral fold which is often observable in Schizophoria resupinata (MARTIN), the type species of Schizophoria, and also in Schizophoria mesoloba JANISCHEWSKI from the Lower Namurian of southern Ural. However, the writer prefers to treat Aulacophoria as a distinct genus from Schizophoria based on its external character.

Neoschizophoria might be derived from Aulacophoria. 
Neoschizophoria otai gen. et sp. nov.

(Pl. 14, Figs. 1-5; Pl. 15, Figs. 1-6)

Material.-Holotype, GK-D 31716; Paratypes, GK-D 31717, 31718, 31719, 31720. Six complete shells, four pedicle valves, and more than 90 brachial valves are available.

Diagnosis.-As for genus.

Description.-Medium to large, strongly dorsi-biconvex shells, approximately two-thirds as thick as wide, two-thirds to four fifths as thick as long, with very narrow hinge line, about two-fifths to three-fifths of greatest width of shell.

Pedicle valve transversely elliptical with highly projected beak; interarea flat, procline with apical angle of about $90^{\circ}$, delthyrium may open; surface characteristically divided into three divisons by a couple of broadly radiating rounded folds with an angle of about $110^{\circ}$, median flabellate area flat and widest, postero-lateral triangular areas very slightly convex; ornament consists of radial capillae and growth lines; former have a density of six in $1 \mathrm{~mm}$ at a distance of $10 \mathrm{~mm}$ from beak, primary capillae stronger than later developing ones; growth lines few but sometimes distinct.

Brachial valve much larger than pedicle valve and extraordinarily convex, posterior half much more convex than anterior one; umbonal part strongly incurved and dorsal beak normally concealed in delthyrium of opposite valve; sulcus broad and shallow, posteriorly obscure but remarkably marked anteriorly, about one-half to one thirds as wide as shell near anterior margin; anterior commissure very weakly unisulcate.

Pedicle valve interior with very thick, stout dental plates, supporting dorsolaterally directed teeth, inner side of distal end sometimes split off at very close to teeth, subparallel to slightly divergent with each other in transverse section, and anteriorly continuous to a couple of stout ridges, surrounding muscle field; ventral muscle field anteriorly extends two-thirds to three-fourths length of valve, gradually increases height, making a distinct platform; low median ridge sometimes developes only in anterior muscle field; no distinct median septum developed in pedicle valve.

Brachial valve interior has deep notothyrial cavity, laterally bordered by thick brachiophore plates; brachiophore strong, projecting in same direction with brachiophore plates; fulcral plates stout, projecting ventro-laterally with angles of about $90^{\circ}$ to brachiophores and support shallow sockets; basal parts of branchiophore plates anteriorly continuous to very low rounded ridges on both sides of muscle fields; characters of muscle fields not recognizable but anterior margin of dorsal muscle fields locate at about a half length of valve; cardinal process in notothyrial cavity first appears as a broad low longitudinal ridge with laterally sloping basal floor and laterally inflated basal part, becoming thinner anteriorly compare with growth of its height, surface of median ridge crenulated without incision of distal end; expanded basal part of median ridge increases lateral inflation as it increases height anteriorly and this bud of new ridges gradually becomes flat-topped and finally completely branches off from median ridge as a couple of low and round-topped, accessory processes, anteriorly parallel 
to median ridge with a sharp and deep groove between median ridge and accessory process; median ridge relatively thin comparing with its height, but rapidly decreases height near anterior margin of cardinal process; accessory processes anteriorly increase strength and height and anterior end of them coincides with that of median ridge, therefore cardinal process anteriorly reveals trilobate structure.

Localities and Horizons.-The Millerella yowarensis zone, Sumitomo quarry, Profusulinella beppensis and Fusulinella biconica zone, Shoboji, Shuho-cho, Minegun, and Pseudostaffella antiqua zone, Maruyama quarry, Isa, Mine-shi, Yamaguchi Prefecture.

Table 1. Measurements (in $\mathrm{mm}$ ) of Neoschizophoria otai gen. et sp. nov.

\begin{tabular}{c|c|c|c|c|c}
\hline Rag. No. & $\begin{array}{c}\text { Length of } \\
\text { pedicle valve }\end{array}$ & $\begin{array}{c}\text { Length of } \\
\text { brachial valve }\end{array}$ & $\begin{array}{c}\text { Maximum } \\
\text { width }\end{array}$ & $\begin{array}{c}\text { Width of } \\
\text { hinge line }\end{array}$ & Thickness \\
\hline Holotype & 25.0 & $30+$ & 37.2 & 20.0 & 24.6 \\
GK-D 31716 & & 30.2 & $26+$ & 20.0 & 23.5 \\
4 Paratypes & 25.7 & 30.5 & $31+$ & 20.0 & 24.0 \\
GK-D 31717 & 23.0 & $11+$ & 15.0 & 8.6 & 8.0 \\
GK-D 31718 & $9.5+$ & 13.4 & $12+$ & 7.8 & 8.2 \\
GK-D 31719 & 10.8 & & & & \\
\hline
\end{tabular}

Table 2. Statistic of length (1), maximum width (w), width of hinge line (h), thickness $(t)$ of 8 pedicle valves and 37 brachial valves of Neoschizophoria otai gen. et sp. nov. s: standard deviation

$$
\begin{array}{lllll}
\text { Pedicle valve : } & \left(\begin{array}{l}
1=18.68 \\
\mathrm{~s}=6.37
\end{array}\right. & \left(\begin{array}{l}
\mathrm{w}=23.49 \\
\mathrm{~s}=8.85
\end{array}\right. & \left(\begin{array}{l}
\mathrm{h}=13.43 \\
\mathrm{~s}=5.38
\end{array}\right. & \left(\begin{array}{l}
\mathrm{t}=6.93 \\
\mathrm{~s}=3.02
\end{array}\right. \\
\text { Brachial valve: } & \begin{array}{l}
\mathrm{l}=28.25 \\
\mathrm{~s}=6.46
\end{array} & \left(\begin{array}{l}
\mathrm{w}=30.12 \\
\mathrm{~s}=7.29
\end{array}\right. & \left(\begin{array}{l}
\mathrm{h}=20.15 \\
\mathrm{~s}=5.22
\end{array}\right. & \left(\begin{array}{l}
\mathrm{t}=16.43 \\
\mathrm{~s}=4.92
\end{array}\right.
\end{array}
$$

\section{Explanation of Plate 14}

Figs. 1-5. Neoschizophoria otai sp. nov. ................. Page 107

1a-c. Ventral, dorsal, and lateral views of a plaster cast of a paratype, GK-D 31717 , from IW-1, the Millerella yowarensis zone, $\times 1$.

2a-e. Posterior, ventral, anterior, lateral, and dorsal views of the holotype, GK-D 31716, from ST-A, the Profusulinella beppensis zone, $\times 1$.

3a-c. Dorsal, ventral, and lateral views of a plaster cast of a paratype, GK-D 31718, from ST-A, $\times 1$.

4a-d. Ventral, dorsal, lateral, and anterior views of a brachial valve, GK-D 31721, from IW-1, $\times 1$.

4e. Enlarged part of an anterior portion of the preceding specimen, showing fine radial ornamentation, $\times 3$.

5a-c. Lateral, dorsal, and ventral views of a brachial valve, GK-D 31722 , from IW-1, $\times 1$. 

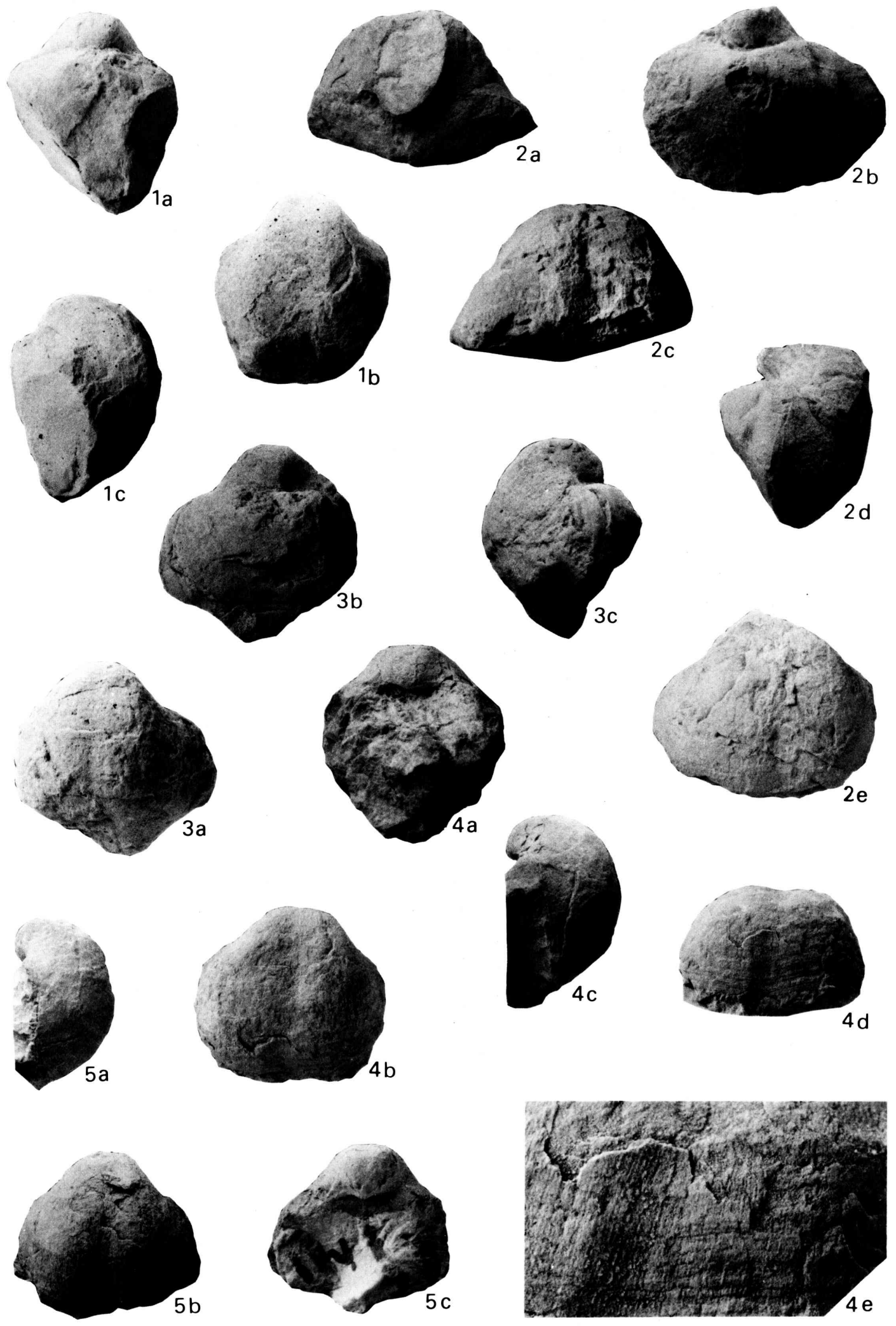

J. YANAGIDA: A New Schizophoriid Genus 

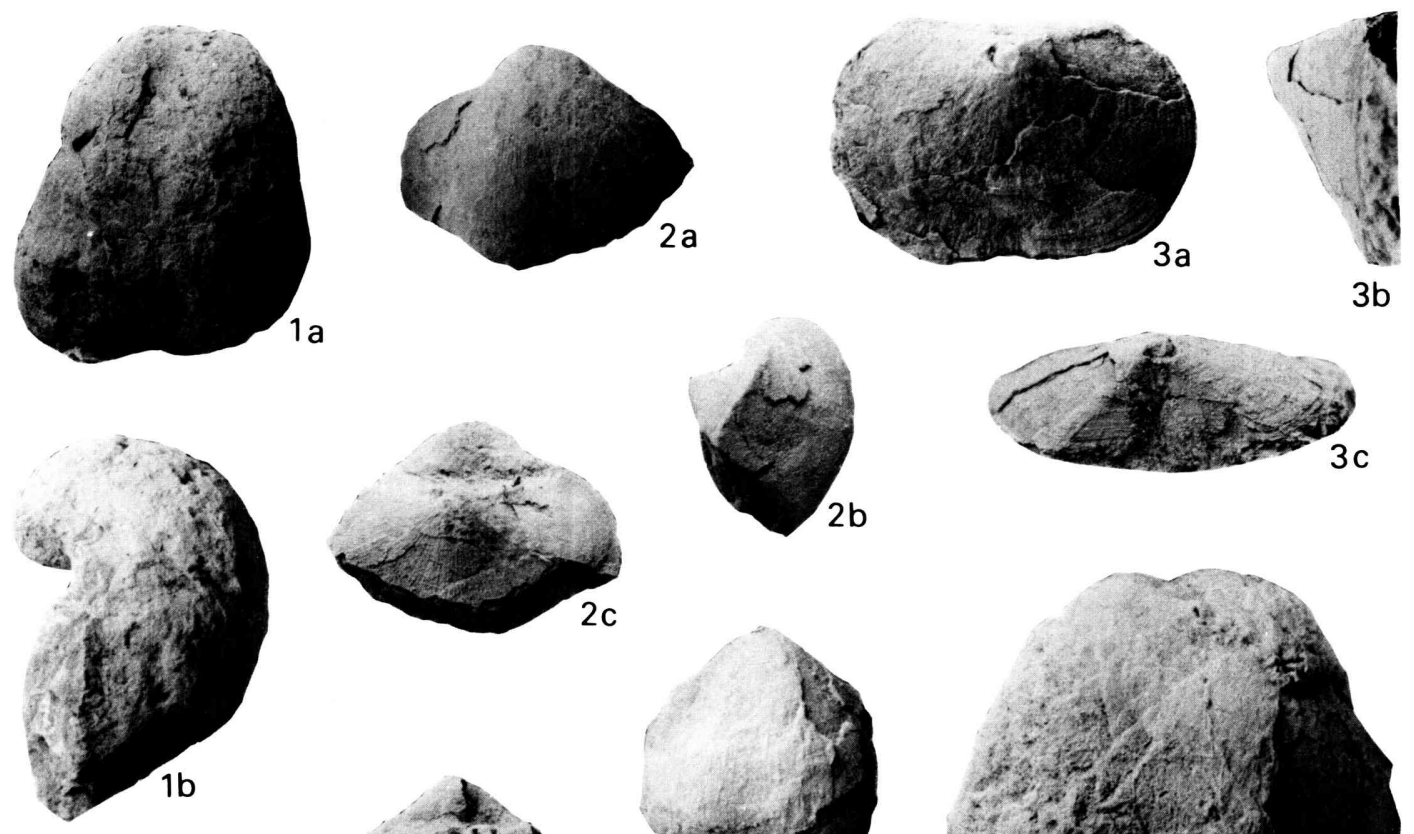

$3 b$
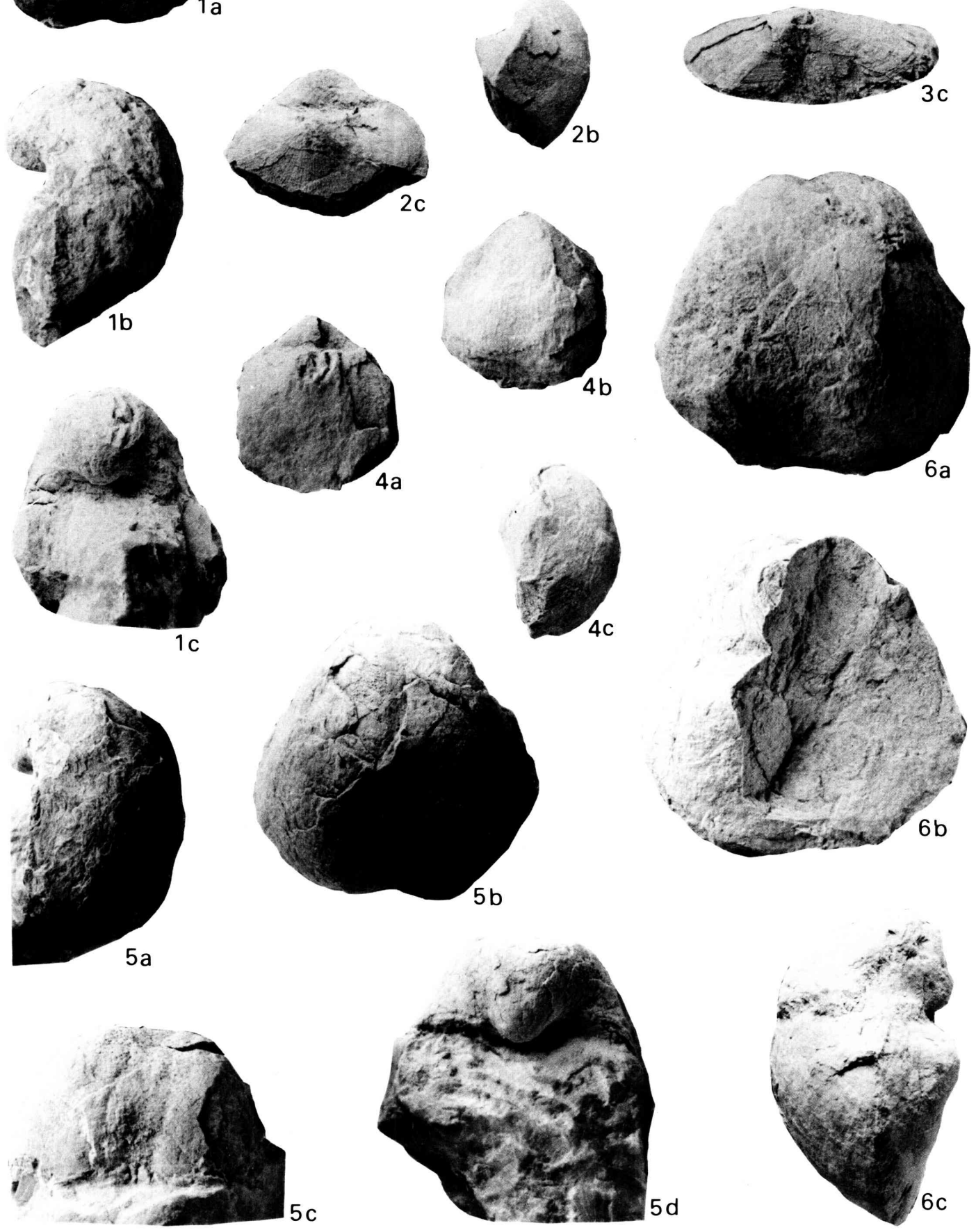

J. YANAGIDA: A New Schizophoriid Genus 
Discussions.-The species is characterized by its strongly convex brachial valves without apparent notothyrium and with completely hidden beak, procline interarea and a couple of broad radial folds on pedicle valve, distinguishing the median flabellate and broadly flat part from a pair of lateral, elongated triangular parts, and a long stout cardinal process with a couple of low accessory processes which were branched off from the posterior base of the cardinal process. The folds on pedicle valve are remarkable although intraspecific variation in its development is recognizable. The holotype specimen from the Profusulinella beppensis zone has the most remarkably developed folds. One of paratype specimens in young stage of growth, GK-D 31719 from the same fusuline zone, also shows the well developed folds. Among specimens of the species it might be suggested that the more or less transverse forms have rather strongly vaulted and incurved dorsal umbo and distinct folds in pedicle valves than the longitudinally rounded ones. Slight variation is also observable in width and depth of sulcus on brachial valve, which appears as a slightly unisulcate commissure at anterior margin. Another intraspecific variation is slightly recognized in form of the cardinal process. However, the anterior modification of the cardinal process during growth is basicaly same among specimens as it is shown by two series of serial sections of different specimens from different ages, Fig. 2 from the Millerella yowarensis zone and Fig. 3 from the Profusulinella beppensis zone.

Principal form of Neoschizophoria otai strongly resembles Aulacophoria keyserlingiana (DE KONINCK) from the upper Visean and Lower Namurian of Western Europe. The former, however, is distinguished from the latter by its larger shell, deeper brachial valve with more convex umbo, less remarkable dorsal sulcus, and complete absence of ventral median fold.

The basic characters on form of Neoschizophoria otai such as the extraordinarily convex brachial valve, the pedicle valve with procline interarea and the surface made up of three distinctive parts, and characteristics of the internal structures are suggestive for giving a significant comprehension on their functional morphology. Thickness of each valve has a key to find the living position

\section{Explanation of Plate 15}

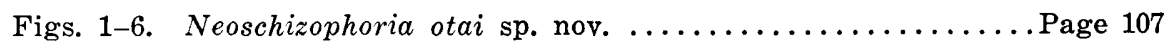

1a-c. Dorsal, lateral, and ventral views of a brachial valve, GK-D 31723, from ISA-42, the Pseudostaffella antiqua zone, $\times 1$.

2a-c. Dorsal, lateral, and ventral views of a paratype, GK-D 31719, from ST-A, the Profusulinella beppensis zone, $\times 2$.

3a-c. Ventral, lateral, and posterior views of a pedicle valve, GK-D 31724, from IW-1, the Millerella yowarensis zone, $\times 2$.

4a-c. Ventral, dorsal, and lateral views of a paratype, GK-D 31720, from ST-A, $\times 2$.

5a-d. Lateral, dorsal, anterior, and ventral views of a brachial valve, GK-D 31725 , from ISA-41, the Pseudostaffella antiqua zone, $\times 1$.

6a-c. Dorsal, ventral, and lateral views of an incomplete shell, GK-D 31726 , from ISA- $42, \times 1$. 


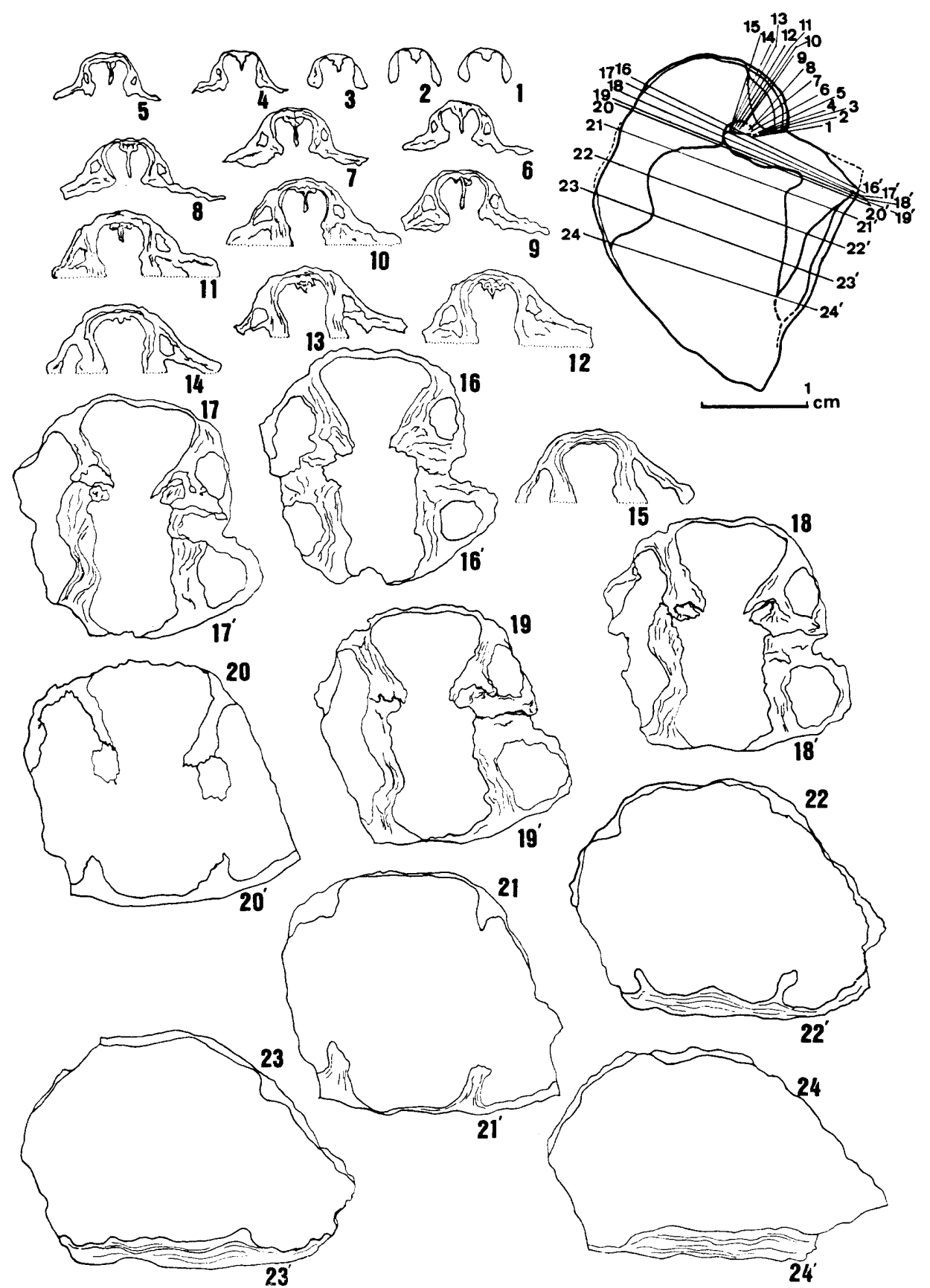

Fig. 4. Serial sections of a paratype specimen of Neoschizophoria otai gen. et sp. nov., GK-D 31718, from ST-A, the Profusulinella beppensis zone, and a longitudinal profile of the same specimen, showing positions of each section and main internal structures. 

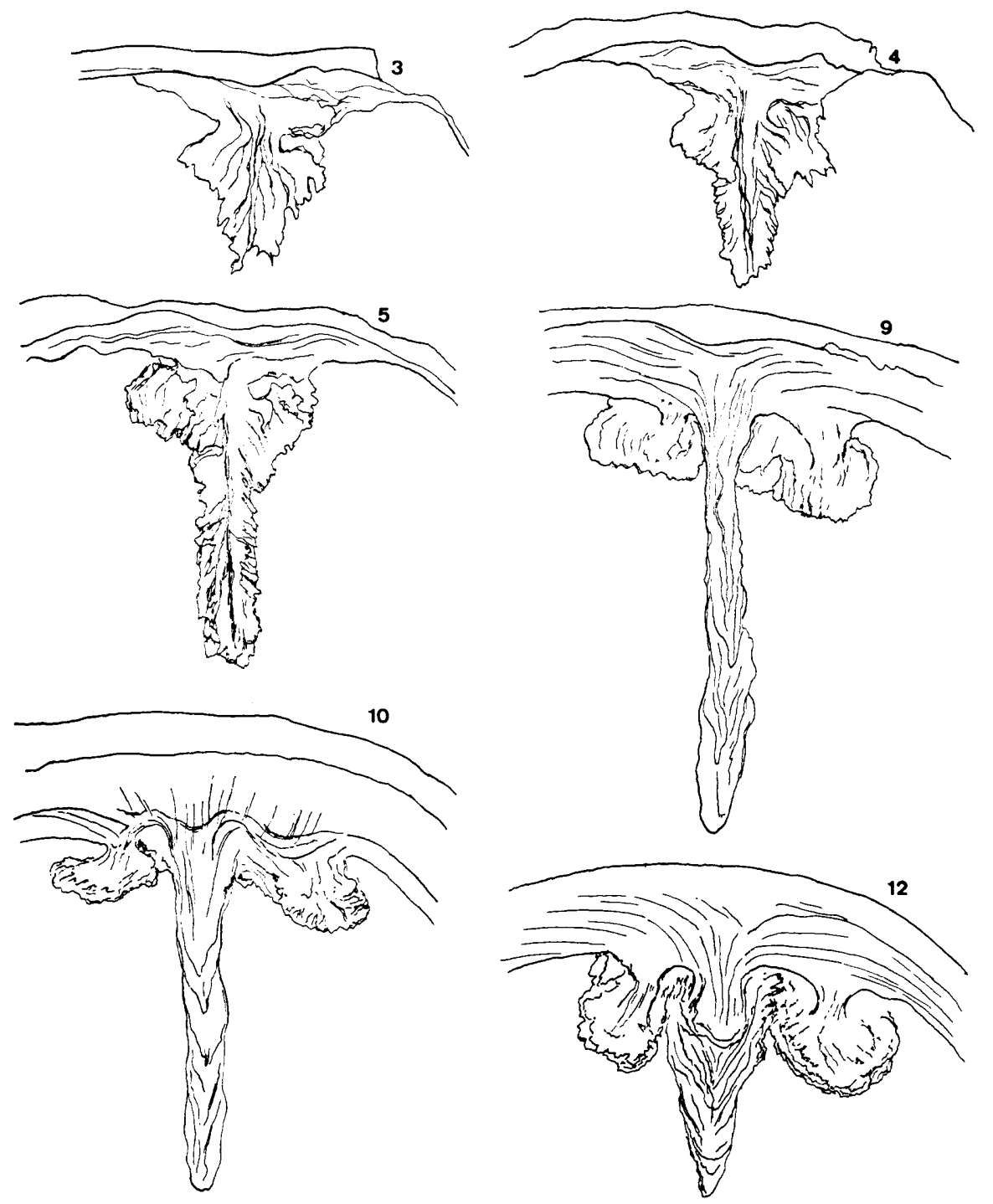

$1 \mathrm{~mm}$

Fig. 5. Enlarged figures of some serial sections of the cardinal process of Neoschizophoria otai gen. et sp. nov. in Fig. 4, showing the detailed structure of the median ridge and accessory processes. Number of each figure corresponds to that of Fig. 3, respectively. 


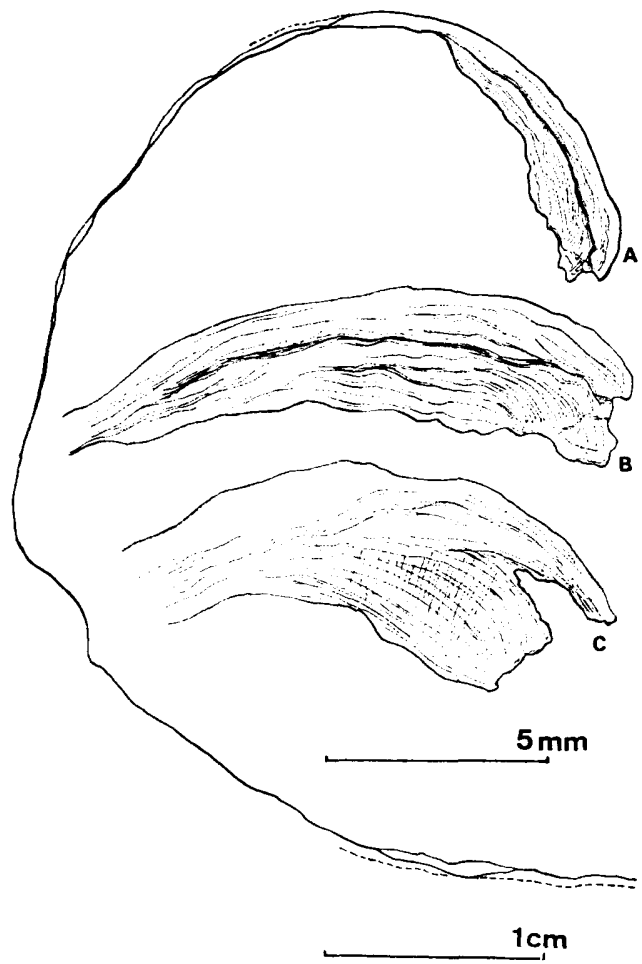

Fig. 6. Median longitudinal section of the cardinal process of a brachial valve of Neoschizophoria otai gen. et sp. nov., GK-D 31730, from ISA-42, the Pseudostaffella antiqua zone. $\mathrm{B}$ and $\mathrm{C}$ are twice as large as $\mathrm{A}$, and $\mathrm{C}$ is the counter section of B. Upper scale bar is for B and $\mathrm{C}$, and the lower one is for $\mathrm{A}$.

and mode of life of shell. In Neoschizophoria otai strongly convex brachial valve is not so thick even though the exfoliation is taken into consideration. No indication of suggesting thick shell was recognized in the posterior part of brachial valve. Pedicle valve interior, to the contrary, has a wide muscle field and this is represented by a remarkably raised platform. This part externally corresponds to the main part of central flabellate area. The lateral elongated triangular parts also have thick shell which is recognized by the serial sections.

In relation with position of the cardinal process of brachial valve to the diductor muscle field of the pedicle valve together with its thick shell, it will probably be considered that the species has a living position of slightly reclining on the pedicle valve with one of the elongated triangular part of pedicle valve and an umbonal part of branchial valve regularly in contact with the sea floor.

Judging from the occurrence of the species at IW-1, ISA-41, and ISA-42, and ST-A and ST-B, the individuals of the species originally lived in a reefal environment very close to the seaward slope. The position where they were concentrated was a channel and consequently it is considered that they originally lived on a 


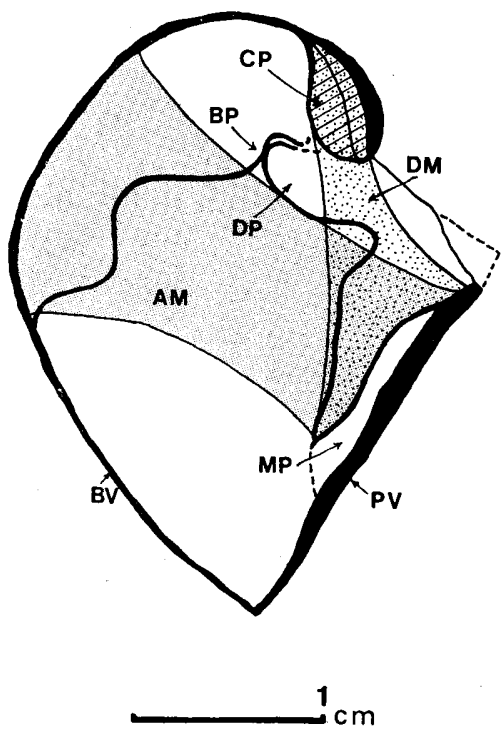

Fig. 7. Reconstruction of main internal structures of Neoschizophoria otai gen. et $\mathrm{sp}$. nov. with inferred position of the adductor and diductor muscles: CP, cardinal process; BP, brachiophore; MP, muscle platform; $A M$, adductor muscle; $D M$, diductor muscle; $B V$, brachial valve; $P V$, pedicle valve; DP, dental plate.
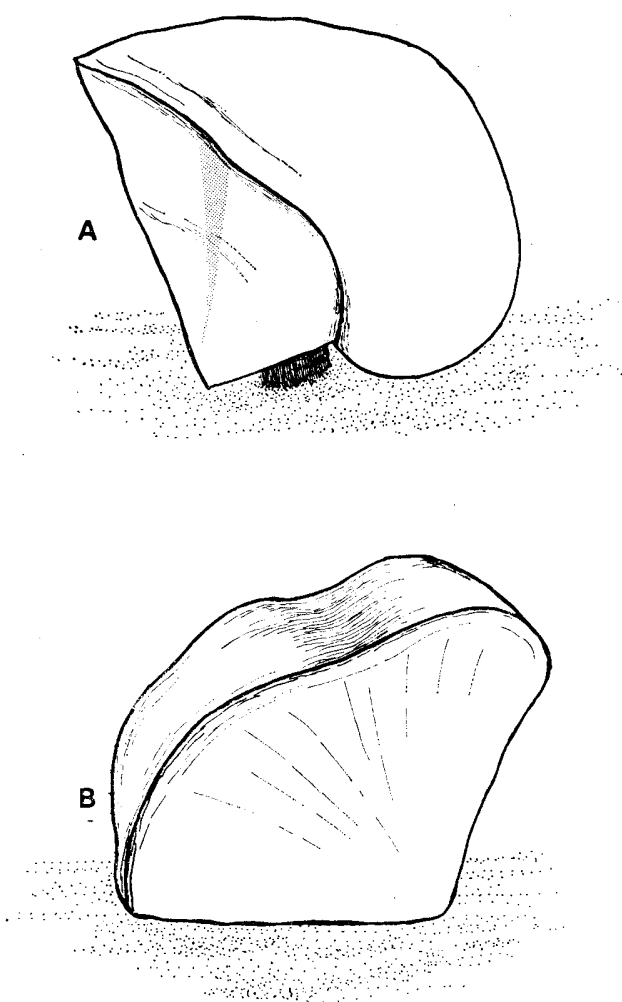

Fig. 8. Inferred living position of Neoschizophoria otai gen. et sp. nov.: A, lateral view; B, ventral view. 
hard bottom or on coarse sediments near channel in a shallow sea environment where agitation of water was effective in good deal for their accumulation.

\section{References Cited}

Brunton, C. H. C. (1968): Silicified brachiopods from the Visean of County Fermanagh (II). Bull. British Museum (Nat. Hist.), Geology, 16, (1), 1-70, pls. 1-9.

George, T. N. and Ponsford, D. R. A. (1938): Notes on the morphology of Schizophoria. Trans. Leeds. Geol. Assoc., 5, 227-245, pl. 5.

HAShimoto, Kyoichi (1979): Bio- and litho-facies of the Akiyoshi limestone Group in the southern area of the Akiyoshi plateau. Bull. Akiyoshi-dai Mus. Nat. Hist., (14), 1-26, pls. 1-12. [in Japanese with English abstract].

LAZAREv, S. S. (1976): Morphology and evolution of brachiopods (of the Superfamily Enteletacea) [in Russia], $140 \mathrm{pp}, 7+15$ pls., Moscow.

NAGAI, Koichi (1979): Organic reef limestone in the lower part of the Akiyoshi limestone Group. Chikyu (The Earth), 1, (9), 661-667. [in Japanese].

NishidA, Tamio (1982): Mid-Carboniferous ammonoids from the Akiyoshi limestone Group (Molluscan paleontology of the Akiyoshi limestone Group-V) Bull. Akiyoshi-dai Mus. Nat. Hist., (17), 1-54, pls. 1-10.

OtA, Masamichi (1968): The Akiyoshi limestone Group: A geosynclinal organic reef complex. Bull. Akiyoshi-dai Sci. Mus. (5), 1-44, pls. 1-31. [in Japanese with English abstract].

(1977) : Geological study of Akiyoshi. Part I. General geology of the Akiyoshi limestone Group. Bull. Akiyoshi-dai Mus. Nat. Hist., (12), 1-33, pls. 1-3.

Ota, Nobuki, Sugrmura, Akihiro and Ota, Masamichi (1969): Reef deposits in the Millerella zone of the Akiyoshi limestone Group. Palaeont. Soc. Japan, Spec. Pap., (14), 1-12, pls. 1-3.

YANAGIDA, Juichi (1962): Carboniferous brachiopods from Akiyoshi, Southwest Japan. Part I. Mem. Fac. Sci., Kyushu Univ., [D], 12, (1), 87-127, pls. 14-21. (1965): Carboniferous brachiopods from Akiyoshi, Southwest Japan. Part II. Ibid., [D], 16, (2), 113-142, pls. 25-28. 